\title{
ENSURING THE QUALITY OF SERVICES BY MAKING COSTS EFFECTIVE IN THE MANAGEMENT OF RURAL TOURIST BOARDING HOUSES
}

\author{
Larisa Dragolea ${ }^{1}$ \\ Radu Matei Todoran ${ }^{2}$
}

ABSTRACT: Lately, the number of the rural boarding houses has grown considerably, the researches registering a progressive evolution. The latest official records provided by the National Institute of Statistics were made in 2007 and they show the considerable numeric growth of the people that have appealed to this kind of host functioning structure. Official data regarding the number of boarding houses existing in our country have not been reported by the authorities in this sector.

The quality costs represent an important quality valorizing instrument, a potential source for maximizing the profit of any economic unit. They are used by more and more entities as a tool for the optimization of processes and activities which are relevant to quality. Through these costs it is likely to identify ineffective activities, the critical points in the development process. Thus, the corrective actions or for improvement needed in a particular sector could be substantiated, ensuring the dynamic follow-up assessment and the effectiveness of measures taken. This is perfectly applicable in the rural tourism sector.

Keywords:quality, services, costs, rural sector

JEL codes: M11, M41

\section{Introduction}

Lately, the number of the rural boarding houses has grown considerably, the researches registering a progressive evolution. The latest official records provided by the National Institute of Statistics were made in 2007 and they show the considerable numeric growth of the people that have appealed to this kind of host functioning structure. Official data regarding the number of boarding houses existing in our country have not been reported by the authorities in this sector.

The quality costs represent an important quality valorizing instrument, a potential source for maximizing the profit of any economic unit. They are used by more and more entities as a tool for the optimization of processes and activities which are relevant to quality. Through these costs it is likely to identify ineffective activities, the critical points in the development process. Thus, the corrective actions or for improvement needed in a particular sector could be substantiated, ensuring the dynamic follow-up assessment and the effectiveness of measures taken. This is perfectly applicable in the rural tourism sector.

Improving the quality of services requires increased consumption of resources, leading to increased costs and charges for their production (by which boarding houses ensure their cost recovery and obtain their profit). Therefore, between the qualitative level of the rural tourism product and the costs level and the related charges a report directly proportional can be accepted.

The lack of a coherent management strategy involves inherent weaknesses for the level of cost management. The awareness of the benefits offered by providing quality services related to a correct level of the prices does not present a common practice today.

\footnotetext{
1 “1 Decembrie 1918” University, No.5, Gabriel Bethlen, larisadragolea@yahoo.com

2 “1 Decembrie 1918” University, No.5, Gabriel Bethlen,martradu@gmail.com
} 
In the service company, the quality represents the key for the market position against competitors. If the other branches can use pricing and other competitive policies, in services the quality remains essential for maintaining - effective and with image - by all methods: the quality, advertising, publicity, all against respecting a business culture which has proved beneficial in time ${ }^{3}$.

Specialty literature stresses the need for the senior management to be aware, respectively managers or owners of rural boarding houses, of the quality provided in terms of the benefits involved when applying this concept, particularly in relation to the other economic variables. In order to be more then a trend for the management of the boarding house, the impact of quality on the respective unit must be demonstrated. It must be associated with items measuring performance, such as cost, market share primarily reflected in the number of customers and profit. Otherwise it will soon lose the interest for improving the quality because of the lack of a rational strategy.

The loss of interest in providing quality services within rural tourist boarding houses will inevitably lead to the disappearance of the provider on the tourist market, which is emphasized by the crisis period that we are crossing.

One of the first specialists who have drawn attention to the different degree of quality management perception and development was PB Crosby in 1979. He has defined five stages, starting from uncertainty to certainty. The description of the defining elements of each stage is based on six "measuring" categories:

- managers' attitude and ability to understand the boarding house's administrator;

- quality status of a company or organization on the market in which it operates;

- the way of addressing the problems in carrying out the activity;

- assessing quality costs as a percentage from services sales;

- the actions taken by the unit in order to improve the quality;

- Characterizing the way in which quality is addressed in the respective unit. Whether it is the quality of services, the quality of staff, the quality of the ambiance etc., it is necessary that all those working in the service sector should not do a service unless this service has quality.

The studies have shown that consumer satisfaction is influenced by the special quality of services, which in turn influences the buying intentions. Unlike the quality of a product, the quality of tourism services is more difficult to define, to judge or express in quantitative terms, as the service has little physical dimensions such as performance, operational characteristics and maintenance costs, which could be used to comparison or measurement. Due to services production and consumption inseparable character, the quality should be defined both on the basis of providing tourism services and on the actual results expressed by consumer's satisfaction. Therefore the solution for measuring the quality of the service is determining how customers evaluate the received benefits. In other words, the appreciations of boarding houses consumers represent the result of the comparison between their expectations and the actual services performances.

The quality of a product or service is the main characteristic when it comes to selling. There are many and diversified factors that determine the success of the sale. They include market conditions, type of product/service, the image created by advertising, socio-cultural peculiarities of customers etc. But the major factor that ensures the marketability of a product/service is its quality as it was approved by the customers.

Repeated and sustained sales can only be obtained on quality products/services at a reasonable price. The interest for a certain boarding house services may decline - under certain circumstances - despite providing quality services and if the products have poor quality, no hostel/accommodation can be maintained on the market for long.

\footnotetext{
${ }^{3}$ Drăgulănescu, N. De la calitate controlată la calitate totală, Bucureşti,Editura Alternative, 1995, pag.71;
} 
Here, we can mention the two sides of quality: the objective and the subjective quality, the first representing the quality reflected by social standards and indicators and the second representing the type of quality - the subjective quality - is what the client considers that he should receive. Correlating them as quickly and as efficiently as possible within the management activity from rural boarding houses will lead to early and significant cost effectiveness.

Regardless of the costs that can be achieved by providing a quality service, the idea that a quality service costs must be emphasized, but the provider will pay higher prices for non-quality. G. Tagughi formulated the following definition: "Quality is the minimum cost that a product or service imposes to society". The definition is based on the following principles: is cheaper to prevent than to repair and do it right from the start. The compliance with these two principles leads to paying a minimum cost for quality, with maximum effects.

The benefit consists both of tourist services and the products offered to customers. The poor quality of products inevitably leads to increased expenses, mainly due to the following factors:

- the flaw of the unsatisfactory products;

- labor costs for the recovery of non-compliant products;

- large stocks due to unsold products;

- waste of time and money to resolve the grievances raised by dissatisfied customers;

- penalties due to failure to meet customers;

The analysis of these additional costs due to poor quality of products led to the conclusion that they can reach $15-20 \%$ of the total cost of product manufacture.

Under certain guidelines, the quality may represent some special aspects:

- in the product orientation - the quality is considered a measurable characteristic

- in the process orientation - there will be taken into account the views of the manufacturer, after that the products/services as are those that meet the requirements, but the user may have a different perspective;

- in the cost orientation (default trading price) - the product/service is considered to be qualitative only if it offers certain performance at an acceptable price level. A quality product is the one that provides performance at an affordable price and in compliance with technical requirements at an acceptable cost. This approach is difficult to apply in practice, because it involves two different concepts: quality and value.

- in the user orientation - the quality is defined as representing the capacity of the product/service to be used (fitness for use). It represents the satisfaction of the recipient regarding the functionality, the safety of the exploitation, price, delivery period, costs of use, compatibility with the environment etc.

In order to perform a tourism services is necessary to take into account all the approaches listed above, thus succeeding to have satisfied customers with minimal costs, which means a profitable activity.

Quality can be analyzed like some balances, meaning comparing the quality costs with negative effects of non-quality. For reaching a certain quality level are necessary expenses that must be weighed against the benefits they have in meeting customer needs, in the functioning of the service unit.

An outsizing of these expenses may prove to be inefficient meaning that the extra quality achieved is not sufficient to justify the increase of costs, but considering the issues mentioned above (mainly referring to the non-quality than to the extra quality of the product) the comparison problem arises mainly with attention to avoid non-quality, this might have major negative effects by losing customers. Competition is large, and ready to recruit the clients of the firm with deficient quality; in many cases there is self-service version.

The quality - non-quality costs analyses can provide a systemic view and new ways of monitoring the functioning of the company and its persistence, stability, possibly increasing chances. 
Most of the time, the management and administrative control focus on temporary benchmarks. The company establishes its objectives concerning the costs, sales, profits, the investments' efficiency etc. During the actual process the company should not forget the importance of competitive advantage, so it should not pursue term objectives related to the business budget, by neglecting the great need to retain the competition power through quality.

J. Kélada proposes the following definition of cost categories which we will adapt to the rural tourism specific:

a) The direct costs of non-quality which are measurable and immeasurable (Table 1)

Table no.1

The direct costs of non-quality

\begin{tabular}{|c|l|}
\hline \multicolumn{2}{|c|}{ A. Measurable costs } \\
\hline 1 & The costs of resuming the services poorly performed \\
\hline 2 & Discounts given for deficiencies or downgraded products \\
\hline 3 & The costs of the flaws \\
\hline 4 & Costs due to canceled tour package \\
\hline 5 & Costs due to additional services \\
\hline 6 & The cost of equipment and facilities bought to ensure quality \\
\hline 7 & Motivational, training and informational programmes for staff on quality \\
\hline 8 & The cost of implementing quality system \\
\hline 9 & Value analysis studies to detect and correct over-capacity \\
\hline 10 & The cost of audits required to ensure quality \\
\hline \multicolumn{2}{|c|}{ B. Immeasurable costs } \\
\hline 11 & $\begin{array}{l}\text { Loss of an order, a customer or a market, because of poor quality service } \\
\text { provision }\end{array}$ \\
\hline 12 & $\begin{array}{l}\text { The cost of temporary work carried out by people from different departments, } \\
\text { to study non-quality problems }\end{array}$ \\
\hline 13 & The use of subcontractors for services that could be sold directly \\
\hline
\end{tabular}

(Source: Hinescu, 2004)

b) The indirect costs of quality, also divided in: measurable and immeasurable (table 2)

Table no. 2

\section{Categories of indirect costs of quality}

\begin{tabular}{|r|l|}
\hline \multicolumn{2}{|c|}{ A. Measurable costs } \\
\hline 1. & $\begin{array}{l}\text { The cost of maintaining a high level of stocks of raw materials, components } \\
\text { and finished products in order to quickly correct the effects of poor } \\
\text { production quality (insufficient) }\end{array}$ \\
\hline 2. & $\begin{array}{l}\text { Some services cost for the correction of the services that are inconsistent with } \\
\text { the requirements }\end{array}$ \\
\hline 3. & $\begin{array}{l}\text { Costs involved in analyzing business competitors, regarding the higher quality } \\
\text { service provision }\end{array}$ \\
\hline 4. & $\begin{array}{l}\text { Cost for resort's image recovery or correction, as a result of the provision of } \\
\text { services that have disappointed customers }\end{array}$ \\
\hline 5. & The cost for assessing the suppliers in order to ensure a quality supply service \\
\hline 6. & Standardization activities \\
\hline 7. & $\begin{array}{l}\text { Increasing the cost for keeping the control and assuring the quality, through a } \\
\text { reduction in the quality level }\end{array}$ \\
\hline 8. & $\begin{array}{l}\text { Loss of sales, because of the non-quality obtained, other competitors intend to } \\
\text { provide similar services or substitutes }\end{array}$ \\
\hline 9. & $\begin{array}{l}\text { Reducing available resources for the development of new products, packages } \\
\text { or services to gain some market segments }\end{array}$ \\
\hline
\end{tabular}


10 Costs due to buying the equipment with greater accuracy

11 The costs involved in the development of new processes

(Source: Hinescu, 2004)

The principles of quality management also provide, in an eloquent way, the need to optimize costs and resources allocated to provide a service. One of the most important "indicators" to control the quality is the cost of quality.

In the planning process, estimating these costs is the starting point for establishing the monitoring and evaluation activities when developing the product or when providing the service. Moreover, assessing the effectiveness of the quality system is achieved mainly by these costs.

For a rural tourism boarding house board to achieve its objectives on quality is necessary to develop and implement a quality management system structured and adapted to the specific type of activity and processes that it develops taking into account also the considerations relating to benefits, costs and risks.

For example a characteristic of the tourist movement relates to the high percentage of transport costs for interest rates. Developing some low transport costs reduces the total costs and stimulates the tourist movement.

Total Quality represents the continuously meeting of the customer requirements in terms of minimum cost. Using TQM, it is ensured the satisfaction of these requirements in terms of minimum costs with the implication of the company's entire staff.

Table no. 3

Comparative characteristics, total quality facing quality

\begin{tabular}{|l|l|}
\hline \multicolumn{1}{|c|}{ Quality } & \multicolumn{1}{c|}{ Total Quality } \\
\hline $\begin{array}{l}\text { The defects are discovered after their } \\
\text { happening }\end{array}$ & The defects are prevented \\
\hline An acceptable level of quality is defined & Zero defects \\
\hline $\begin{array}{l}\text { The quality control is assigned to a special } \\
\text { person }\end{array}$ & $\begin{array}{l}\text { The quality control is the issue for every } \\
\text { employee }\end{array}$ \\
\hline $\begin{array}{l}\text { The customer pays the additional costs } \\
\text { involved for quality control }\end{array}$ & Quality costs are kept under control \\
\hline Quality is expensive & \begin{tabular}{l} 
Quality pays \\
pesigning and manufacturing quality with the \\
\hline Quality results from product
\end{tabular} \\
\hline
\end{tabular}

Quality is what makes the difference between a service and another, between one provider and another. Quality services can provide access to international markets; quality reduction may be compromising, is very expensive, and can be harmful and sometimes impossible to recover. A quality service brings immediate and lasting satisfaction to the clients, tourists and also to the provider.

Improving the quality of services requires increased consumption of resources, leading to increased costs and charges for their production (by which boarding houses provide cost recovery and obtain their profit). Therefore, between the quality level of rural tourism product and the costs level and the related charges a report directly proportional can be accepted.

The importance of quality increases simultaneously with empowering the position of customers, which in turn attracts increasing need to advisably manage the quality.

Thus, it requires the action in the following domains:

- the harmonization of tourism legislation to similar regulations in European Union;

- support for the establishment of professional associations and other NGOs in tourism, developing and organizing the partnership of the National Authority for Tourism 
- improving the quality of tourism promotions by using the budgetary funds for this area (compared with EU countries).

The actions to support rural tourism initiated by authorized agencies should aim at the following priority objectives:

- fiscality reduction

- non-taxation of reinvested profits in a certain period;

- the continuous improvement of the legal and institutional framework for its harmonization with the rules of World Tourism Organization and European Union

- the involvement of the state in the financial support for the rural tourism investments, particularly those of public interest (infrastructure) and for the international and domestic tourism promotion;

- the development of specialized professional training and retraining system for the labor force that was laid off from other economic sectors; establishing a tourism education institutions network integrated in the European tourism education camps network.

- Correlating the tourism development programmes and projects with regional development programmes (transport, telecommunications, landscaping etc.);

- Imposing the quality brands in order to enhance competitiveness in the rural tourism market and recognizing the tourism service quality.

According to the principle: is better to be 1\% better than competitors in 100 service than $100 \%$ better in a single service (Jan Carlzon), the administrators of rural boarding houses must aim at assuring the quality at all levels when providing a service, whatever its nature, only in this way the quality costs can be controlled and amortized in a short time.

Quality costs do not represent an absolute measure of performance. They must be properly integrated into the system of evaluating the overall efficiency of the unit's management.

\section{References}

1. Briciu, S., "Contabilitate analitică şi de gestiune", Editura Ulise, Alba Iulia, 2002

2. Crosby, P. B., - Quality Without Tears: The Art of Hassle-free Management, New York, McGraw- Hill, 1984

3. Dima, I.C., Grabara J., Budgeting Costs of Production in a Firm, Arves, Craiova, Romania, 2008

4. Drăgulănescu, N. De la calitate controlată la calitate totală, Bucureşti,Editura Alternative, 1995

5. Garvin, D., Managing Quality: Te Strategies and Competitive Edge ,The Free Press, New York, 1988

6. Hinescu, A., Oneţiu, Gh., Managementul total al calităţii (TQM), Editura Risoprint, Cluj-Napoca, 2004

7. Juran, J. M., Supremaţia prin calitate, Editura Teora, Bucureşti, 2002.

8. Kelada, J., La gestion integrale de la qualite. Pour une qualite totale, Edition Quebec, Quebec, 1990

9. Lazăr, I., Ilieş, L., Mortan, M., Popa, M., Lungescu, D., Vereş, V., Managementul firmei, Editura Risoprint, Cluj-Napoca 2006.

10. Mortan, M., “Agroturismul- o alternativă posibilă”,Editura Dacia, Cluj-Napoca 2005.

11. Parker Graham, W. , Costurile calităţii, Codecs, 1998

12. Stoian, M., Managementul pensiunii, Manual şi supliment legislativ, apărut sub egida Autorităţii Naţionale pentru Turism şi ANTREC, 2005. 